\title{
Immune Curbing of Cancer Stem Cells by CTLs Directed to NANOG
}

\author{
Christina Wefers ${ }^{1,2}$, Gerty Schreibelt ${ }^{1}$, Leon F. A. G. Massuger ${ }^{2}$, I. Jolanda M. de Vries ${ }^{1 *}$ \\ and Ruurd Torensma ${ }^{1}$ \\ ${ }^{1}$ Department of Tumor Immunology, Radboud Institute for Molecular Life Sciences, Radboudumc, Nijmegen, Netherlands, \\ ${ }^{2}$ Department of Obstetrics and Gynecology, Radboudumc, Nijmegen, Netherlands
}

\section{OPEN ACCESS}

Edited by:

Matteo Bellone,

San Raffaele Hospital

(IRCCS), Italy

Reviewed by:

Elena Jachetti,

Istituto Nazionale dei Tumori

(IRCCS), Italy

Serena Pellegatta,

Fondazione IRCCS Istituto

Neurologico C. Besta, Italy

*Correspondence:

I. Jolanda M. de Vries

jolanda.devries@radboudumc.nl

Specialty section:

This article was submitted

to Cancer Immunity and

Immunotherapy,

a section of the journal

Frontiers in Immunology

Received: 06 April 2018

Accepted: 06 June 2018

Published: 19 June 2018

Citation:

Wefers C, Schreibelt G, Massuger LFAG, de Vries IJM and Torensma $R$ (2018) Immune

Curbing of Cancer Stem Cells

by CTLs Directed to NANOG.

Front. Immunol. 9:1412. doi: 10.3389/fimmu.2018.01412
Cancer stem cells (CSCs) have been identified as the source of tumor growth and disease recurrence. Eradication of CSCs is thus essential to achieve durable responses, but CSCs are resistant to current anti-tumor therapies. Novel therapeutic approaches that specifically target CSCs will, therefore, be crucial to improve patient outcome. Immunotherapies, which boost the body's own immune system to eliminate cancerous cells, could be an alternative approach to target CSCs. Vaccines of dendritic cells (DCs) loaded with tumor antigens can evoke highly specific anti-tumor $\mathrm{T}$ cell responses. Importantly, DC vaccination also promotes immunological memory formation, paving the way for long-term cancer control. Here, we propose a DC vaccination that specifically targets CSCs. DCs loaded with NANOG peptides, a protein required for maintaining stem cell properties, could evoke a potent anti-tumor immune response against CSCs. We hypothesize that the resulting immunological memory will also control newly formed CSCs, thereby preventing disease recurrence.

Keywords: dendritic cell vaccination, cancer stem cells, MHC class I, NANOG, cancer stem cell immunity

\section{CURRENT APPROACHES TO TARGET CANCER STEM CELLS (CSCs)}

CSCs form a rare population of tumor cells with a unique ability to self-renew. Although CSCs proliferate slowly, they give rise to more differentiated, fast-growing tumor cells that sustain and fuel tumor growth. Their low proliferation rate, combined with the expression of drug transporters, enables CSCs to survive classical anti-tumor treatments. Furthermore, continuous genomic and epigenomic changes allow CSC to develop new resistance mechanisms that can be passed on to their progeny (1). Current anti-tumor therapies targeting the tumor bulk thus often fail to eliminate CSCs.

The realization that eradicating CSCs is essential to prevent disease relapse has greatly stimulated CSC research. The search term "cancer stem cells" yields over 75,000 hits in PUBMED, and numerous papers describe CSC proteins and their pathways. This has lead to different treatment strategies that target CSC, either by inducing CSC killing, by forcing their differentiation, or by inhibiting key signaling pathways.

Initially, large libraries of small molecules were screened for candidates that kill CSCs [for a recent review see Ref. $(2,3)]$. These molecules target different key signaling pathways of CSCs. Salinomycin was one of the first compounds discovered (3). Another example is the small molecule IGC-001 which affects the Wnt pathway by interfering with $\beta$-catenin (4). NOTCH signaling could be inhibited through $\gamma$-secretase inhibition of MK-0752 (5). The two FDA approved drugs Vismodegib and Erismodegib block the Hedgehog signaling pathway and are tested in clinical trials for the treatment of basal-cell carcinoma (6-8). 
Aside from synthetic molecules, also naturally occurring small molecules and food components can interfere with CSC signaling. A vast number of papers describe the signaling targets of these natural compounds and the mechanisms of CSCs killing [for review see Ref. (9)]. Several compounds showed inhibiting functions in vitro $(10,11)$. Statistical analyses even demonstrated that eating cruciferous vegetables $(12,13)$ can prolong survival of cancer patients. Curcumin is effective in several tumors. However, curcumin only works at high dosage ( $8 \mathrm{~g} /$ day), probably because its low solubility limits availability. A modified, more soluble form of curcumin is, therefore, being tested in several trials (14). Although food components killed tumor cells in vitro, they could not prevent cancer development in vivo (15-17). A likely reason for this discrepancy is that food mostly contains inactive precursors of active compounds. For example, only a minority of people has an intestinal flora that promotes the conversion of the precursor glucoraphanin into the CSCs inhibitor sulforaphane $(18,19)$.

Just like their synthetic counterparts, natural small molecules from food components affect the Hedgehog-, the Wnt-, and the Notch-Jagged signaling pathways. However, this approach can result in severe side effects, as these signaling pathways are also essential for normal stem cells. Stem cells in the colon crypts-which are crucial for regenerating and sustaining colon tissue-depend on the Wnt pathway. Targeting Wnt signaling, therefore, comes with a risk of collateral damage (20-22).

To prevent these side effects, antibody-drug conjugates (ADCs) can be used to specifically target and kill CSCs via cell surface markers, such as LGR5, CD133, or DLL3 (23-25). Even though these ADCs showed promising results in murine experimental models of colon and lung cancer, their success should be interpreted with caution. CSC markers are heterogeneously expressed on the stem cell population, and to date, none of the identified surface markers is specific for CSCs (26). Aspecific ADCs may also eradicate normal stem cells that share surface markers with CSCs. Furthermore, the instability of current ADCs in the circulation may lead to premature drug release and offtarget toxicity (27).

Another approach induces terminal differentiation of CSCs through epigenetic targeting. The best-known example is alltrans retinoic acid, which is used to treat acute promyelocytic leukemia. This compound induces histone modifications that force CSCs to differentiate (28). Similarly, histone deacetylases (HDAC) are promising targets in CSCs, as several clinically available HDAC inhibitors can preferentially target CSCs in vitro (29). However, little is known about the epigenetic regulation of CSC and treatment with HDAC inhibitors could cause toxicity by disrupting gene regulation in normal tissue stem cells.

Even though current approaches to target CSCs in solid tumors are promising, they do face major challenges. First, reliable CSC-specific markers and signaling pathways need to be identified to prevent off-target effects. Second, none of these strategies can cope with CSC plasticity, the interconversion of CSCs and more differentiated tumor cells. Eradication of CSCs can only be achieved if these problems are adequately addressed.

\section{STEM CELL TRANSCRIPTION FACTORS ARE IDEAL TARGETS TO INHIBIT CSCs}

The best way to kill CSCs is to target their unique proteins, not or low expressed by somatic cells (30). Candidates are the transcription factors OKT4a, SOX2, c-MYC, and KLF4, which also transform somatic cells into stem cells (iPS) (31). Most types of cancers express several of these transcription factors in a low percentage of cells (32-35), although some cancer types express only one or two of these transcription factors (36-38). Another candidate is the transcription factor NANOG, which regulates several cellular functions (Figure 1) (39). NANOG is required for maintaining stem cell properties and is re-expressed in a wide array of cancers (40-44). It furthermore promotes cell proliferation, migration, and metastasis, likely by downregulation of cell-cell interactions via E-cadherin (45) and control of cell cycle-related proteins (46). NANOG also renderers CSCs resistant to chemotherapy, for example, by inhibition of p53-mediated apoptosis (47). Expression of NANOG and its pseudo genes is low or absent in normal cells, making it an ideal therapeutic target (48-51).

\section{Expression of Stem Cell Factor NANOG in CSCs}

Expression of NANOG in CSCs is detected in a variety of cancer types, including glioma (34), breast cancer (52), ovarian cancer (53), and lung cancer (54). The realization that the resistant cancer cells driving tumor recurrence after classical treatment express NANOG $(34,51,55-60)$ have prompted the development of NANOG inhibitors. These inhibitors were remarkably successful in experimental models (42, 51, 55, 61-63). For example, activator-like effector nuclease (TALEN) was able to disrupt NANOG function in Hela cells in vitro, increasing chemosensitivity and reversing the epithelial-to-mesenchymal transition (64). In breast cancer cells, shRNA against NANOG reduced cell proliferation and migration (46). However, in vivo targeting of these compounds to CSCs will be a major challenge. Furthermore, wiping out NANOG by TALEN or shRNA $(46,64-66)$ will not suffice to eradicate cancer. Through a process known as plasticity, differentiated cancer cells become CSCs by re-expressing NANOG (67-71), which also occurs in nonpathogenic cells (72). NANOG inhibiting compounds like RNAi or small inhibitors, therefore, have to be given lifelong to keep the tumor encaged. Thus, although NANOG may be suitable to specifically target CSCs, there is a need for novel strategies that can also control new CSCs arising through plasticity.

\section{THE IMMUNE SYSTEM AS CSC KILLER}

Our body has developed a unique strategy to provide long-term protection from pathogens and cancerous cells: the immune system. Tumor infiltration by CD8 immune cells is associated with prolonged patient survival (73). However, these $\mathrm{CD}^{+} \mathrm{T}$ cells are often unable to eradicate the tumor because of inhibition by other, immunosuppressive cells in the tumor microenvironment, such as regulatory $\mathrm{T}$ cells $\left(\mathrm{T}_{\text {regs }}\right)$. To reflect the strength of this 


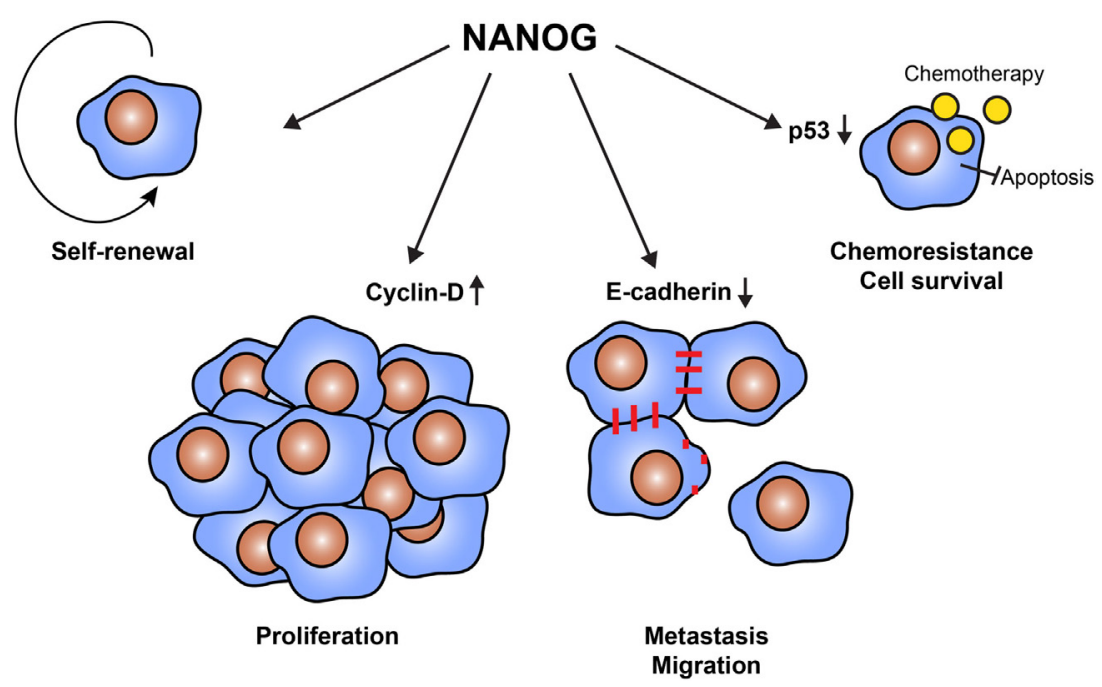

FIGURE 1 | Cellular functions of NANOG in cancer stem cells (CSCs). The transcription factor NANOG is expressed by CSCs and has a variety of functions. NANOG is essential to maintain the self-renewal properties of CSCs. Furthermore, NANOG regulates cell proliferation via the interaction with cell cycle proteins, such as cyclin D. It also downregulates the expression of E-cadherin, enabling cells to detach and migrate to form distant metastases. Finally, NANOG promotes cell survival and resistance to therapy. NANOG interferes with the tumor suppressor p53, protecting cells from apoptosis.

immunosuppression, an "immunoscore" of a tumor can be computed as the ratio between immune stimulating and immune inhibiting cells (74). Immunotherapies aim to tip this balance toward immune activation. For example, immune checkpoint antibodies alleviate immunosuppression and increase patient survival, proving that the immune system can combat cancer.

However, can the immune system also prevent further cancer growth by attacking stem cell antigens? The first indication comes from a study where the immune system was activated by vaccinating with glioblastoma lysate of either normal cancer cells or CSCs (75). The quantity of stem cell antigens is much higher in the CSC lysate, which evokes a better immune response against the cancer. Other studies have shown that cancer patients as well as healthy subjects can have immunological memory against OCT4, a CSC transcription factor $(76,77)$. However, this memory response could not cure or prevent cancer. Full responses appear to require rejuvenation of the immune system by means of DCs loaded with tumor antigens (78). Nevertheless, the existence of immunological memory against CSC transcription factors is promising, as it suggests that it should be possible to generate long-lasting immune responses that control the CSCs driving tumor growth.

\section{The Tumor Uses Several Ways to Stop Immune-Mediated Killing}

An important reason why existing anti-tumor immune cells fail to eradicate the tumor is active immunosuppression by the tumor microenvironment. Surviving tumors have escaped immunological clearance by paralyzing the immune system, exploiting several natural mechanisms by which the body can dampen immune reactions. These mechanisms include the attraction of immunosuppressive cells $\left(\mathrm{T}_{\text {regs }}\right.$, myeloid-derived suppressor cells), induction of inhibitory cytokines (IL-10, TGF- $\beta$ ), reduction of MHC class I expression, expression of metabolic enzymes, such as indoleamine 2,3-dioxygenase and arginase (which breakdown either tryptophan or arginine, respectively) (79), and the PD-1-PD-L1 axis $(80,81)$. Mesenchymal stem cells (MSCs) that form part of the tumor microenvironment are able to inhibit the immune system. In vitro-cultured MSCs express NANOG and the expression of immune-modulatory role is dependent on NANOG. Destroying NANOG in activated MSCs in the tumor bed by the immune system will limit the immune inhibitors and is an added advantage (82). Yet another way to prevent immune attack is modification of the lipid pathways, resulting in a block of T-cell proliferation (83). Checkpoint antibodies relieve part of this inhibition and thereby prolong overall survival (84). However, as tumors use multiple immunosuppressive strategies, a single antagonist will be unable to fully abrogate immunosuppression and eradicate the tumor. It is, therefore, crucial to also look at other methods to tip the balance back in favor of anti-cancer immunity.

\section{Cytotoxic T Cells Need Target Molecules to Kill Tumor Cells}

Another factor that may hamper T cell responses against CSCs is insufficient expression of HLA class I. Before cytotoxic T lymphocytes (CTLs) can kill a tumor cell, they must first recognize tumor antigens presented on HLA class I. Whereas, several studies reported reduced expression of HLA class I on CSCs, other studies nevertheless found a cytotoxic CD8 T cell response against CSCs [reviewed in Ref. (85)]. CSCs lacking HLA class I should be recognized by NK cells. In ovarian cancer, NK cells obtained from CD34 hematopoietic stem cells destroy cancer cells in a sphere assay, a classical way to culture CSCs (86).

MHC class I expression in stem cell marker positive cells can be analyzed using single cell $\mathrm{m}$-RNA sequencing. The Broad Institute performed single cell mRNA sequencing in oligodendrogliomas 
CSCs and their differentiated offspring (Figure 2) (87). A stem cell score and a lineage score was computed for each cell, enabling classification as stem cell, astrocyte, or oligodendrocyte. These data are available online (https://portals.broadinstitute.org/ single_cell), and allowed us to investigate HLA class I expression on CSCs. Analysis showed that CSCs express HLA-A and B (Figure 3). Only a minority of CSCs and mature cancer cells did not express HLA class I.

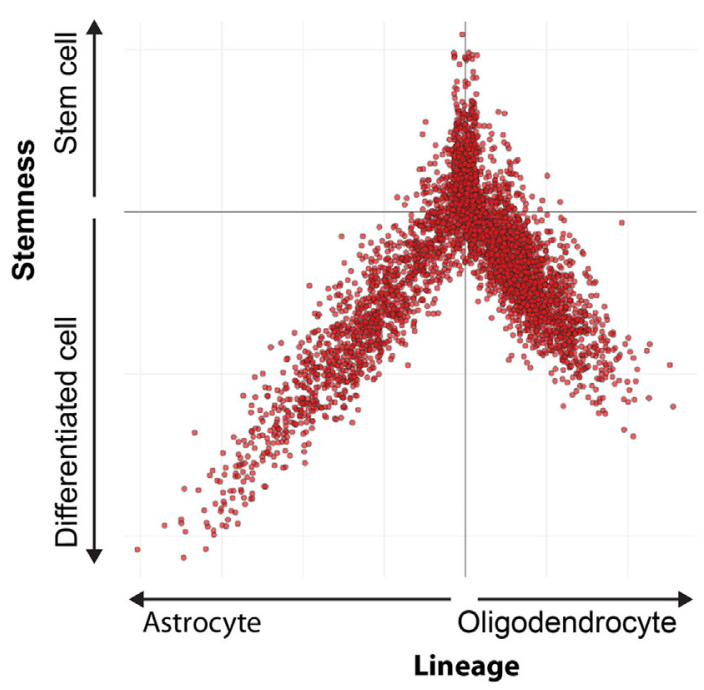

FIGURE 2 | Differentiation hierarchy in oligodendrogliomas. Differentiation hierarchy based on differentiation scores $(X)$ and stem cell scores $(Y)$. Three distinct expression programs: oligodendrocyte (positive $X$, negative $Y$ ), astrocyte (negative $X$, negative $Y$ ), and stem cells (positive $Y$ ). Each dot represents a single cell. Reprinted by permission from Tirosh et al. (87).
Although these results suggest that it is feasible to evoke a CTL response against CSCs, HLA class I negative CSCs and mature cancer cells will escape elimination, forming a phenotype invincible by $\mathrm{CD}^{+} \mathrm{T}$ cells (88). These cells regain HLA class I during this dedifferentiation (89). This "soft" HLA class I loss can be resolved by administering IFN- $\gamma$ or revering epigenetic modifications via HDAC inhibitors (90).

Importantly, we detected HLA class I on NANOG positive cells in ascites of ovarian cancer patients (Figure 4), whereas NANOG negative tumor cells were partially HLA class I negative. Apparently, the conversion of more mature cancer cells into CSCs (plasticity) requires epigenetic changes that allow re-expression of HLA class I. These findings suggest that CSCs expressing NANOG should be vulnerable for CD8 attack.

\section{VACCINATION AGAINST NANOG: CTL MEMORY AS GUARD AGAINST CSCs}

Dendritic cell vaccination could evoke cytotoxic T cells directed to CSCs and might induce immunological memory. Thus, this approach could not only eradicate existing CSCs but also provide the long-term ability to remove new CSCs arising through plasticity.

While over 100 trials have tried to boost the immune system by injecting autologous DCs loaded with aberrantly expressed or mutated proteins (neoantigens) $(91,92)$, only a few DC vaccination trials try to target CSCs. Several problems currently hamper the efficacy of these DC vaccination approaches against CSCs. First, they generally rely on isolation of autologous CSCs and loading of DCs with CSC lysates $(75,93,94)$, a personal approach that is labor intensive and is hindered by the current lack of surface makers that can reliably isolate CSCs. Second,
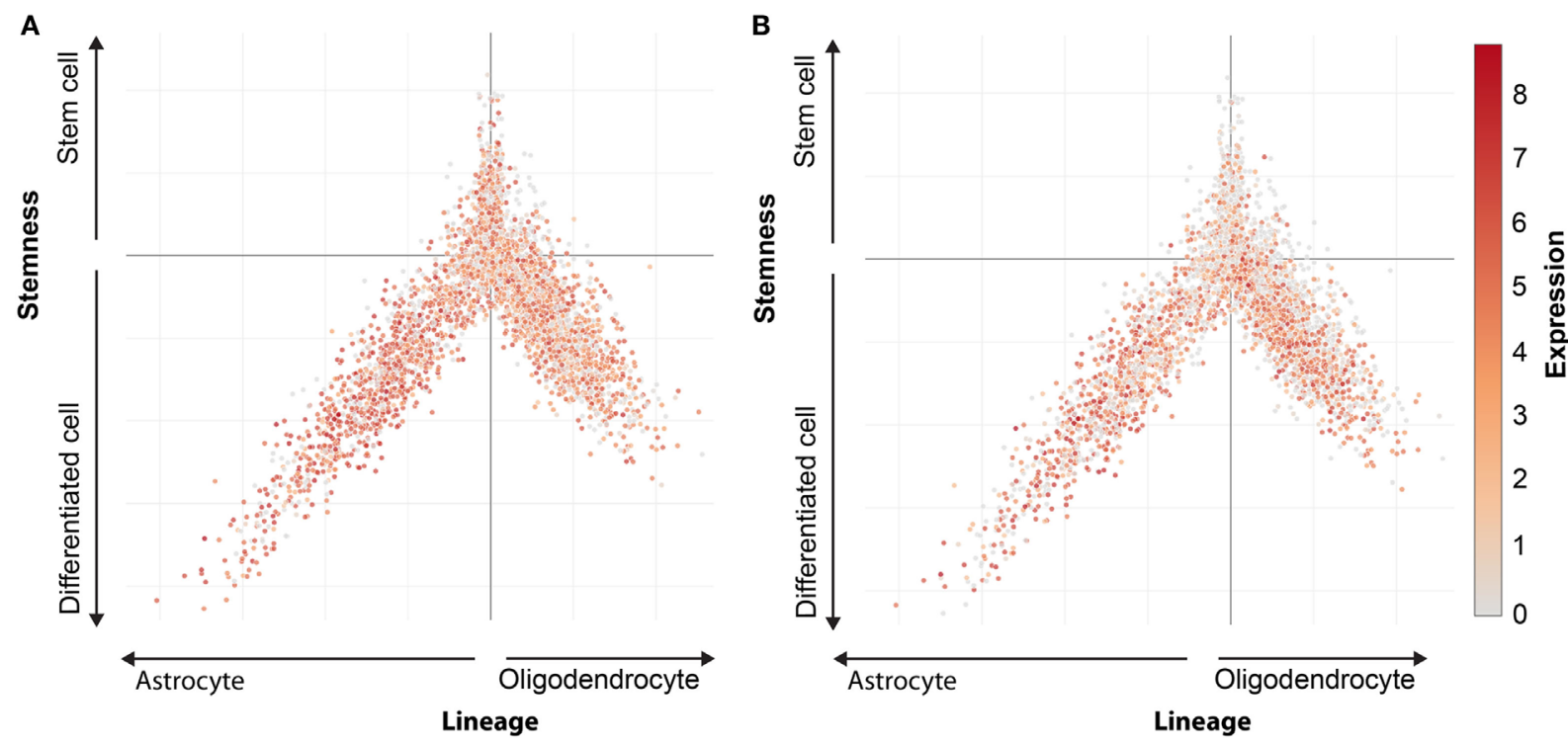

FIGURE 3 | HLA expression in oligodendroglioma. Expression pattern of HLA-A (A) and HLA-B (B) in oligodendrocytes, astrocytes, and cancer stem cells. Every dot represents a single cells. Oligodendrocytes lineage (positive $X$, negative $Y$ ), astrocytes lineage (negative $X$, negative $Y$ ), and stem cells (positive $Y$ ). Expression level indicated by colors from gray (low expression) to red (high expression). 

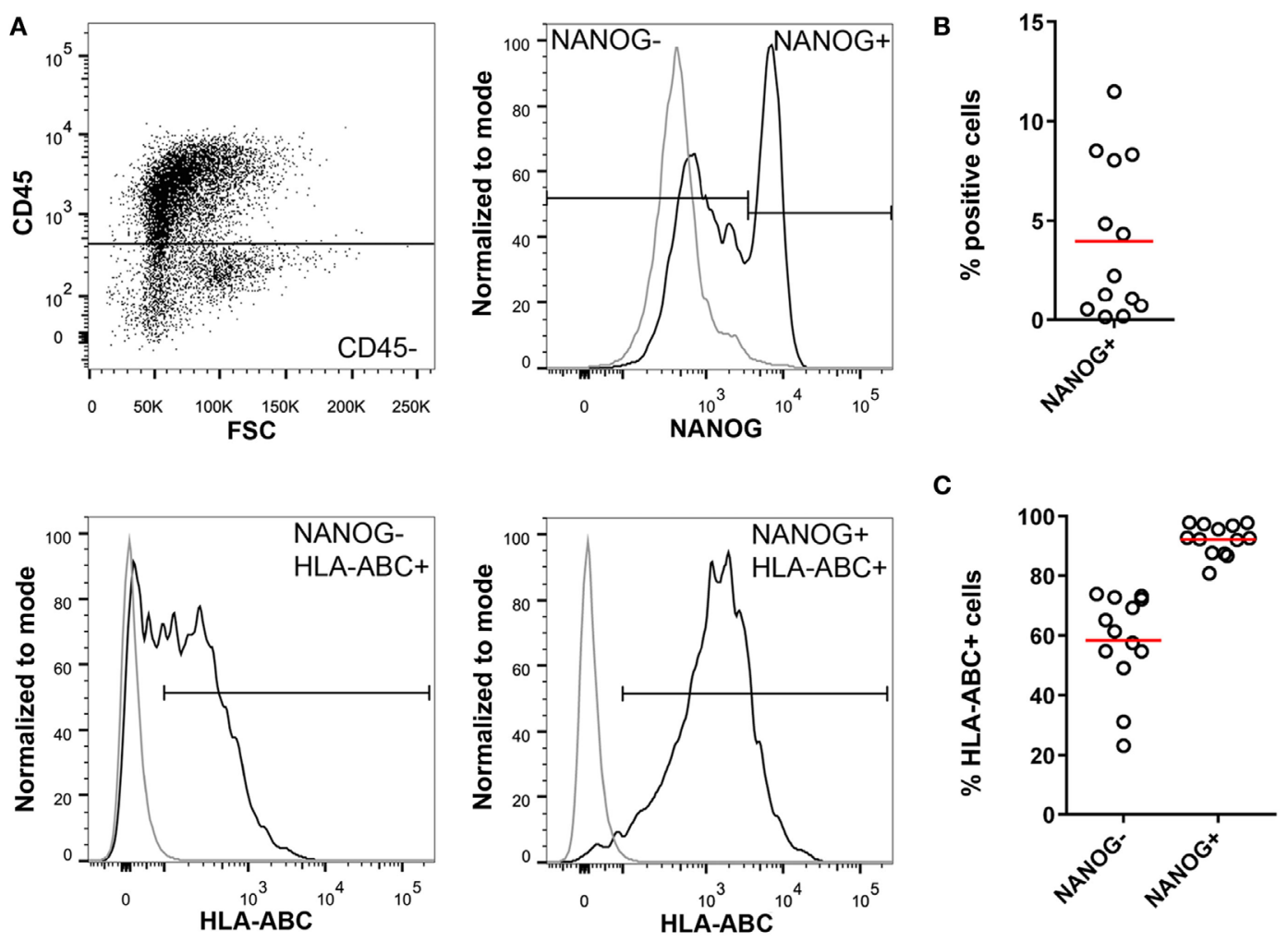

FIGURE $4 \mid$ Cancer stem cells in high-grade serous ovarian cancer ascites. (A) Isolated mononuclear cells from ascites of ovarian cancer patients $(n=13)$ were stained for CD45, NANOG, and HLA-ABC. NANOG positivity was assessed in the CD45- population to exclude immune cells. NANOG- and NANOG+ cells were gated and HLA-ABC expression was analyzed in both populations. Gray line $=$ isotype control; black line $=$ sample. (B) Percentage of NANOG+ cells in ascites. (C) Percentage of HLA-ABC positive cells in the NANOG- and NANOG+ population. Red line indicates mean.

it remains unknown which neoantigens in the lysate elicit an immune response, and the number of these immunogenic neoantigens depends on the tumor. For example, colon cancer has five times more mutations than breast cancer (95). A high mutation rate increases the chance that neoantigens are presented to the immune system. But, neoantigens also need to bind with strong affinity to HLA class I molecules, as this determines the strength of the immune response (96). Current DC vaccination strategies against CSCs, therefore, have limited control over the initiated immune response and might not be suitable for every tumor type.

A more elegant way to eradicate CSCs is to load autologous DCs with specific peptides rather than tumor lysate, as this approach would provide better control over the immune response generated. Specifically, we propose loading DCs with NANOG peptides. Because cancer cells re-express NANOG when they regain stem cell properties, generation of immunological memory after DC vaccination against NANOG would help the immune system to cope with CSC plasticity.

We, therefore, used the NetMHCpan algorithm to determine which peptides from the NANOG protein can bind to HLA class I (97). Several HLA types are able to bind multiple NANOG peptides that could be presented to T cells (Table 1). In patients with HLA types that lack strong binders (e.g., HLA-A2), peptides from other CSC transcription factors, such as SOX2 or OKT4a, could be used (Table 2). As individuals generally have 4 to 6 different
HLA class I molecules, cocktails of NANOG peptides that bind to the different HLA molecules should induce a potent immune response against CSCs. These results suggest that it is feasible to create DC vaccines tuned to the needs of individual patients.

\section{WHY DO WE NOT HAVE MEMORY T CELLS?}

Apparently, no immunity against NANOG exists in normal conditions or cancer would never develop. This suggests that while antigen-presenting cells may present NANOG, this presentation fails to trigger cytotoxic T cells. Several factors may account for this discrepancy. The strength of the immune response depends on the duration of antigen presentation, the affinity of peptides for HLA, and the abundance of peptides. The latter is evident from melanoma, where a normal protein (gp100) becomes immunogenic upon upregulation in malignant cells $(98,99)$. The peptides presented on the cell's surface are continuously refreshed to reflect the internal intracellular pool of peptides. Peptides of less expressed proteins will typically be presented on HLA molecules in very low quantities that will be rapidly replaced for more abundant peptides. Moreover, both CSCs and DCs, the main presenters of antigenic peptides, are extremely rare. The chance that a DC encounters a CSC presenting NANOG peptides is, therefore, very low. Thus, immunity against NANOG requires 
TABLE 1 | Predicted peptides from NANOG that bind to the most common HLA-A types.

\begin{tabular}{|c|c|c|c|c|c|}
\hline Pos & HLA & Peptide & Score & $\%$ Rank & BindLevel \\
\hline 128 & HLA-A ${ }^{\star} 01: 01$ & LSNILNLSY & 0.925578 & 0.0772 & $\leq \mathrm{SB}$ \\
\hline 288 & HLA-A*01:01 & QTMDLFLNY & 0.876012 & 0.122 & $\leq \mathrm{SB}$ \\
\hline 170 & HLA-A*01:01 & SAPTYPSLY & 0.553264 & 0.4238 & $\leq \mathrm{SB}$ \\
\hline 275 & HLA-A*01:01 & NVIQQTTRY & 0.402377 & 0.669 & $\leq \mathrm{WB}$ \\
\hline 233 & HLA-A*01:01 & NQAWNSPFY & 0.263582 & 1.033 & $\leq \mathrm{WB}$ \\
\hline 285 & HLA-A*01:01 & STPQTMDLF & 0.212155 & 1.2491 & $\leq \mathrm{WB}$ \\
\hline 27 & HLA-A*01:01 & VICGPEENY & 0.125078 & 1.9183 & $\leq \mathrm{WB}$ \\
\hline 131 & HLA-A*02:01 & ILNLSYKQV & 0.236804 & 1.29 & $\leq \mathrm{WB}$ \\
\hline 266 & HLA-A*02:01 & ALEAAGEGL & 0.195211 & 1.5189 & $\leq \mathrm{WB}$ \\
\hline 124 & HLA-A*02:01 & QMQELSNIL & 0.18792 & 1.5702 & $\leq \mathrm{WB}$ \\
\hline 297 & $H L A-A^{*} 02: 01$ & SMNMQPEDV & 0.150866 & 1.8894 & $\leq \mathrm{WB}$ \\
\hline 147 & HLA-A*03:01 & RMKSKRWQK & 0.726852 & 0.1333 & $\leq \mathrm{SB}$ \\
\hline 288 & HLA-A*03:01 & QTMDLFLNY & 0.521822 & 0.3469 & $\leq \mathrm{SB}$ \\
\hline 78 & HLA-A*03:01 & TSAEKSVAK & 0.453863 & 0.4542 & $\leq \mathrm{SB}$ \\
\hline 160 & HLA-A*03:01 & KNSNGVTQK & 0.229502 & 1.0894 & $\leq \mathrm{WB}$ \\
\hline 79 & HLA-A*03:01 & SAEKSVAKK & 0.170143 & 1.3846 & $\leq \mathrm{WB}$ \\
\hline 143 & HLA-A*03:01 & FQNQRMKSK & 0.150921 & 1.5158 & $\leq \mathrm{WB}$ \\
\hline 129 & HLA-A*03:01 & SNILNLSYK & 0.103267 & 1.9548 & $\leq \mathrm{WB}$ \\
\hline 282 & HLA-A*24:02 & RYFSTPQTM & 0.944242 & 0.0464 & $\leq \mathrm{SB}$ \\
\hline 135 & HLA-A*24:02 & SYKQVKTWF & 0.808316 & 0.1963 & $\leq \mathrm{SB}$ \\
\hline 173 & HLA-A*24:02 & TYPSLYSSY & 0.745947 & 0.2532 & $\leq \mathrm{SB}$ \\
\hline 205 & HLA-A*24:02 & TWSNQTQNI & 0.563898 & 0.4686 & $\leq \mathrm{SB}$ \\
\hline 285 & HLA-A*24:02 & STPQTMDLF & 0.452306 & 0.6464 & $\leq \mathrm{WB}$ \\
\hline 240 & HLA-A*24:02 & FYNCGEESL & 0.356878 & 0.8489 & $\leq \mathrm{WB}$ \\
\hline 276 & HLA-A*24:02 & VIQQTTRYF & 0.261095 & 1.1693 & $\leq \mathrm{WB}$ \\
\hline 292 & HLA-A*24:02 & LFLNYSMNM & 0.247165 & 1.2256 & $\leq \mathrm{WB}$ \\
\hline 218 & HLA-A*24:02 & NHSWNTQTW & 0.233086 & 1.2872 & $\leq \mathrm{WB}$ \\
\hline 213 & HLA-A*24:02 & IQSWSNHSW & 0.194124 & 1.4867 & $\leq \mathrm{WB}$ \\
\hline 235 & HLA-A*24:02 & AWNSPFYNC & 0.15336 & 1.7525 & $\leq \mathrm{WB}$ \\
\hline 157 & HLA-A*24:02 & NWPKNSNGV & 0.129894 & 1.959 & $\leq \mathrm{WB}$ \\
\hline 275 & HLA-A*26:01 & NVIQQTTRY & 0.945984 & 0.0055 & $\leq \mathrm{SB}$ \\
\hline 288 & HLA-A*26:01 & QTMDLFLNY & 0.925988 & 0.0076 & $\leq \mathrm{SB}$ \\
\hline 50 & HLA-A*26:01 & TVSPLPSSM & 0.436104 & 0.2259 & $\leq \mathrm{SB}$ \\
\hline 285 & HLA-A*26:01 & STPQTMDLF & 0.420456 & 0.2396 & $\leq \mathrm{SB}$ \\
\hline 170 & HLA-A*26:01 & SAPTYPSLY & 0.327707 & 0.3584 & $\leq \mathrm{SB}$ \\
\hline 233 & HLA-A*26:01 & NQAWNSPFY & 0.135179 & 0.9734 & $\leq \mathrm{WB}$ \\
\hline 49 & HLA-A*26:01 & ETVSPLPSS & 0.12096 & 1.0868 & $\leq \mathrm{WB}$ \\
\hline 268 & HLA-A*26:01 & EAAGEGLNV & 0.114943 & 1.1405 & $\leq \mathrm{WB}$ \\
\hline 128 & HLA-A*26:01 & LSNILNLSY & 0.100328 & 1.2837 & $\leq \mathrm{WB}$ \\
\hline 173 & HLA-A*26:01 & TYPSLYSSY & 0.100053 & 1.2865 & $\leq \mathrm{WB}$ \\
\hline 246 & HLA-A*26:01 & ESLQSCMQF & 0.094491 & 1.3466 & $\leq \mathrm{WB}$ \\
\hline 276 & HLA-A*26:01 & VIQQTTRYF & 0.078035 & 1.5685 & $\leq \mathrm{WB}$ \\
\hline 166 & HLA-A*26:01 & TQKASAPTY & 0.071117 & 1.6778 & $\leq \mathrm{WB}$ \\
\hline 169 & HLA-A*26:01 & ASAPTYPSL & 0.059168 & 1.9468 & $\leq \mathrm{WB}$ \\
\hline
\end{tabular}

Peptide length 9; rank threshold for strong binding peptide 0.500; rank threshold for weak binding peptide 2.000; SB, strong binding; WB, weak binding; predicted peptides were generated using NetMHCpan Version 4.0 (http://www.cbs.dtu.dk/services/NetMHCpan/).

a boost by either vaccination or by administration of DCs loaded with NANOG peptides. This approach would increase the number of DCs presenting CSC antigens, and also allows for the selection of suitable peptides based on the patient's HLA type.

\section{DO IN VITRO RAISED CTL KILL CSCs?}

To assess the potential of vaccination with NANOG-loaded DCs, it is crucial to investigate whether CTLs raised against NANOG in vitro are capable of killing CSCs. Current approaches come with limitations that make it difficult to assess the killing capacity of CTLs directed to CSCs. For example, recent data indicate that
TABLE 2 | Predicted SOX2 and OCT4A peptides that bind to HLA-A.

\begin{tabular}{|c|c|c|c|c|c|}
\hline Pos & HLA & Peptide & Score & \% Rank & BindLevel \\
\hline \multicolumn{6}{|c|}{ sox2 } \\
\hline 275 & HLA-A*02:01 & SMYLPGAEV & 0.669833 & 0.2687 & $\leq \mathrm{SB}$ \\
\hline 131 & HLA-A*02:01 & LLAPGGNSM & 0.42905 & 0.6673 & $\leq \mathrm{WB}$ \\
\hline 58 & HLA-A*02:01 & KMAQENPKM & 0.375814 & 0.7882 & $\leq \mathrm{WB}$ \\
\hline 125 & HLA-A*02:01 & YTLPGGLLA & 0.257884 & 1.1925 & $\leq \mathrm{WB}$ \\
\hline 236 & HLA-A*02:01 & ALGSMGSW & 0.203653 & 1.468 & $\leq \mathrm{WB}$ \\
\hline 216 & $H\left\llcorner A-A^{*} 02: 01\right.$ & YMNGSPTYS & 0.146827 & 1.9276 & $\leq \mathrm{WB}$ \\
\hline \multicolumn{6}{|c|}{ OCT4A } \\
\hline 268 & HLA-A*02:01 & GLEKDWRV & 0.719995 & 0.2203 & $\leq \mathrm{SB}$ \\
\hline 249 & HLA-A*02:01 & FLQCPKPTL & 0.645456 & 0.2944 & $\leq \mathrm{SB}$ \\
\hline 72 & $H\left\llcorner A-A^{*} 02: 01\right.$ & GMAYCGPQV & 0.492133 & 0.5388 & $\leq \mathrm{WB}$ \\
\hline 203 & $H\left\llcorner A-A^{\star} 02: 01\right.$ & LLQKWVEEA & 0.419854 & 0.6892 & $\leq \mathrm{WB}$ \\
\hline 163 & $H\left\llcorner A-A^{\star} 02: 01\right.$ & TQADVGLTL & 0.372758 & 0.795 & $\leq \mathrm{WB}$ \\
\hline 332 & HLA-A*02:01 & ALYSSVPFP & 0.166148 & 1.7452 & $\leq \mathrm{WB}$ \\
\hline 93 & HLA-A*02:01 & SQPEGEAGV & 0.164799 & 1.7569 & $\leq \mathrm{WB}$ \\
\hline
\end{tabular}

Peptide length 9; rank threshold for strong binding peptide 0.500; rank threshold for weak binding peptide 2.000; SB, strong binding; WB, weak binding; predicted peptides were generated using NetMHCpan Version 4.0 (http://www.cbs.dtu.dk/services/ NetMHCpan/).

adherent cells only harbor a minute amount of CSCs, but it is hard to generate a cell line from tumor tissue.

To circumvent this problem, it is possible to grow spheroids from tumor tissue using low adhesive culture plates and special, serum-free media supplemented with the growth factors EGF and FGF (100-105). As these cultures go into apoptosis when the CSC is destroyed, as shown for the food supplements and NK cells (86), T cell killing of CSCs can be investigated by analyzing the shrinkage of spheroids co-cultured with in vitro raised $\mathrm{T}$ cells.

However, spheroids are rather simple structures that do not capture the complexity of an organ and are thus unsuitable to assess side effects. So far, we do not know if immunity to NANOG is detrimental for the patient. For melanoma patients, we sometimes observe vitiligo around a reactive mole, indicating that CTLs also attack normal melanocytes. Although in vivo experiments in xenotransplanted mice with siRNA against NANOG did not show adverse effects on normal mouse tissues. These results should be interpreted with caution as it is unknown whether siRNA also inhibits murine Nanog. Moreover, mice have a different MHC class I and thus present other peptides from murine Nanog.

\section{Organoids as a Method to Explore the Safety of Vaccination With NANOG-Loaded DC}

Organoids from CSCs and normal stem cells would be a better approach to test both the efficacy and safety of CTLs raised against NANOG (106-109). Organoids are 3D structures grown from stem cells that are able to recapitulate organ structure and organ-specific cell types. They can be grown from embryonic or induced pluripotent stem cells, from organ-restricted adult stem cells, or from isolated CSCs. Organoid models currently exist for many different tissues, including brain, lung, small intestine, and kidney $(110,111)$. Living NANOG-expressing stem cells can be obtained by labeling cells with NANOG nanoflares and sorting the positive cells $(112,113)$. This enables to test DC vaccination 
against NANOG in a more natural 3D environment, solving the limitations of current in vitro and in vivo approaches.

\section{CONCLUSION}

Reduction of the tumor mass, by either surgery or radiotherapy, is typically the first treatment for solid tumors. However, complete removal of the tumor mass is impossible in some cancer types, leading to disease recurrence when chemotherapy fails to eradicate remaining CSCs. DC vaccination against NANOG could solve this problem by specifically removing CSCs that fuel cancer growth. Importantly, these vaccines can be tuned to the patient's HLA type to maximize response rates. If NANOG peptides cannot be presented by a patient's HLA class I molecules, peptides against other stem cell transcription factor SOX2 or OKT4 may be used.

Despite the promise of this CSC targeting approach, durable immune responses will likely require a combination of DC vaccination with other therapies. Chemotherapy is not suitable in combination with DC vaccination, as it attacks hematopoietic cells in the bone marrow, making it difficult to recover enough autologous DCs for vaccination. To ensure an optimal immune response, inhibiting cells and soluble inhibitors should be removed as much as possible. Combining DC vaccination against NANOG with immune checkpoint inhibitors might help to overcome immunosuppressive mechanisms, and thereby potentiate the immune response directed against NANOG.

\section{MATERIALS AND METHODS}

\section{Patient Material}

Ascites was obtained from stage III and IV high-grade serous ovarian cancer patients before start of the treatment. The study was carried out in accordance with the guidelines and regulation of the Radboudumc. The protocol was approved by the "Commissie Mensgebonden Onderzoek" (CMO ArnhemNijmegen). All subjects gave informed consent in accordance with the Declaration of Helsinki. Some samples were obtained before written consent was needed. Ascites was considered as waste material and only oral informed consent was necessary. All patients gave this oral informed consent to help future patients and were aware that it was not for their own benefit but for research purposes.

\section{Flow Cytometry Staining}

Mononuclear cells from ascites were isolated using Ficoll-gradient centrifugation (Axis Shield) (114). Cells were washed with PBA (PBS/0.5\% BSA/0.01\% $\mathrm{NaN}_{3}$ ) and blocked for $10 \mathrm{~min}$ in PBA with $2 \%$ FcR blocking reagent (Miltenyi). Afterwards, cells were

\section{REFERENCES}

1. Nassar D, Blanpain C. Cancer stem cells: basic concepts and therapeutic implications. Annu Rev Pathol Mech Dis (2016) 11:47-76. doi:10.1146/ annurev-pathol-012615-044438

2. Ren F, Shen J, Shi H, Hornicek FJ, Kan Q, Duan Z. Novel mechanisms and approaches to overcome multidrug resistance in the treatment of incubated for 30 min with a-CD45-V450 (1:50, BS Biosciences) and a-HLA-ABC-APC (1:4, Miltenyi). Subsequently, cells were fixed in $4 \%$ PFA and permeabilized with PBA containing $0.5 \%$ saponin (Sigma). Next, cells were incubated for $30 \mathrm{~min}$ with a-NANOG-PE (R\&D Systems). Samples were measured on a BD FACS Verse and analyzed using FlowJo Version 10.

\section{DATA AVAILABILITY STATEMENT}

The datasets analyzed for this study can be found in the Broad Institute single cell portal (https://portals.broadinstitute.org/single_ cell/study/oligodendroglioma-intra-tumor-heterogeneity\#studysummary). All other relevant datasets for this study are included in the manuscript.

\section{ETHICS STATEMENT}

Ascites was obtained from stage III and IV high-grade serous ovarian cancer patients before start of the treatment. The study was carried out in accordance with the guidelines and regulations of the Radboudumc. The protocol was approved by the "Commissie Mensgebonden Onderzoek" (CMO Arnhem-Nijmegen). All subjects gave informed consent in accordance with the Declaration of Helsinki. Some samples were obtained before written consent was needed. Ascites was considered as waste material and only oral informed consent was necessary. All patients gave this oral informed consent to help future patients and were aware that it was not for their own benefit but for research purposes.

\section{AUTHOR CONTRIBUTIONS}

CW and GS performed and analyzed immunological experiments. LM collected ascites and took care of informed consent. RT designed the study. RT and CW wrote the manuscript. JdV supervised the study. All authors reviewed the manuscript and approved the final version.

\section{ACKNOWLEDGMENTS}

The single cell data were generously extracted from the Broad Institute single cell portal Cambridge, MA 02142, USA. The hints of Dr. Itay Tirosh and Dr. Mario Suva to analyze the data are greatly acknowledged. The peptide predicting software was from DTU Bioinformatics Kongens, Lyngby, Denmark. We thank Inge Wortel for editing the manuscript.

\section{FUNDING}

This work was supported by an EU grant [PROCROP 635122]. ovarian cancer. Biochim Biophys Acta (2016) 1866:266-75. doi:10.1016/j. bbcan.2016.10.001

3. Gupta PB, Onder TT, Jiang G, Tao K, Kuperwasser C, Weinberg RA, et al. Identification of selective inhibitors of cancer stem cells by high-throughput screening. Cell (2009) 138:645-59. doi:10.1016/j.cell.2009.06.034

4. Chan KC, Chan LS, Ip JC, Lo C, Yip TT, Ngan RK, et al. Therapeutic targeting of $\mathrm{CBP} / \beta$-catenin signaling reduces cancer stem-like population and 
synergistically suppresses growth of EBV-positive nasopharyngeal carcinoma cells with cisplatin. Sci Rep (2015) 5:9979. doi:10.1038/srep09979

5. Fouladi M, Stewart CF, Olson J, Wagner LM, Onar-Thomas A, Kocak M, et al. Phase I trial of MK-0752 in children with refractory CNS malignancies: a pediatric brain tumor consortium study. J Clin Oncol (2011) 29:3529-34. doi:10.1200/JCO.2011.35.7806

6. Sekulic A, Migden MR, Oro AE, Dirix L, Lewis KD, Hainsworth JD, et al. Efficacy and safety of vismodegib in advanced basal-cell carcinoma. $N$ Engl J Med (2012) 366:2171-9. doi:10.1056/NEJMoa1113713

7. Singh BN, Fu J, Srivastava RK, Shankar S. Hedgehog signaling antagonist GDC-0449 (vismodegib) inhibits pancreatic cancer stem cell characteristics: molecular mechanisms. PLoS One (2011) 6:e27306. doi:10.1371/journal. pone. 0027306

8. Nanta R, Kumar D, Meeker D, Rodova M, Van Veldhuizen PJ, Shankar S, et al. NVP-LDE-225 (erismodegib) inhibits epithelial-mesenchymal transition and human prostate cancer stem cell growth in NOD/SCID IL2R $\gamma$ null mice by regulating BMI-1 and microRNA-128. Oncogenesis (2013) 2:e42. doi:10.1038/oncsis. 2013.5

9. Vanamala J. Food systems approach to cancer prevention. Crit Rev Food Sci Nutr (2017) 57:2573-88. doi:10.1080/10408398.2015.1028023

10. McCubrey JA, Lertpiriyapong K, Steelman LS, Abrams SL, Yang LV, Murata RM, et al. Effects of resveratrol, curcumin, berberine and other nutraceuticals on aging, cancer development, cancer stem cells and microRNAs. Aging (Albany NY) (2017) 9:1477-536. doi:10.18632/aging.101250

11. Prud'homme GJ. Cancer stem cells and novel targets for antitumor strategies. Curr Pharm Des (2012) 18:2838-49. doi:10.2174/138161212800626120

12. Terry P, Wolk A, Persson I, Magnusson C. Brassica vegetables and breast cancer risk. JAMA (2001) 285:2975-7. doi:10.1001/jama.285.23.2975

13. Nechuta S, Caan BJ, Chen WY, Kwan ML, Lu W, Cai H, et al. Postdiagnosis cruciferous vegetable consumption and breast cancer outcomes: a report from the after breast cancer pooling project. Cancer Epidemiol Biomarkers Prev (2013) 22:1451-6. doi:10.1158/1055-9965.EPI-13-0446

14. Gupta SC, Patchva S, Aggarwal BB. Therapeutic roles of curcumin: lessons learned from clinical trials. AAPS J (2013) 15:195-218. doi:10.1208/s12248012-9432-8

15. Hossain DM, Bhattacharyya S, Das T, Sa G. Curcumin: the multi-targeted therapy for cancer regression. Front Biosci (Schol Ed) (2012) 4:335-55. doi: $10.2741 / \mathrm{s} 272$

16. Lacerda L, Pusztai L, Woodward WA. The role of tumor initiating cells in drug resistance of breast cancer: implications for future therapeutic approaches. Drug Resist Updat (2010) 13:99-108. doi:10.1016/j.drup.2010.08.001

17. Li Y, Zhang T. Targeting cancer stem cells by curcumin and clinical applications. Cancer Lett (2014) 346:197-205. doi:10.1016/j.canlet.2014.01.012

18. Saha S, Hollands W, Teucher B, Needs PW, Narbad A, Ortori CA, et al. Isothiocyanate concentrations and interconversion of sulforaphane to erucin in human subjects after consumption of commercial frozen broccoli compared to fresh broccoli. Mol Nutr Food Res (2012) 56:1906-16. doi:10.1002/ mnfr.201200225

19. Houghton CA, Fassett RG, Coombes JS. Sulforaphane: translational research from laboratory bench to clinic. Nutr Rev (2013) (11):709-26. doi:10.1111/ nure. 12060

20. van Es JH, Jay P, Gregorieff A, van Gijn ME, Jonkheer S, Hatzis P, et al. Wnt signalling induces maturation of Paneth cells in intestinal crypts. Nat Cell Biol (2005) 7:381-6. doi:10.1038/ncb1240

21. Muncan V, Sansom OJ, Tertoolen L, Phesse TJ, Begthel H, Sancho E, et al. Rapid loss of intestinal crypts upon conditional deletion of the Wnt/Tcf- 4 target gene c-Myc. Mol Cell Biol (2006) 26:8418-26. doi:10.1128/MCB.00821-06

22. Batlle E, Clevers H. Cancer stem cells revisited. Nat Med (2017) 23:1124-34. doi:10.1038/nm.4409

23. Junttila MR, Mao W, Wang X, Wang BE, Pham T, Flygare J, et al. Targeting LGR5+ cells with an antibody-drug conjugate for the treatment of colon cancer. Sci Transl Med (2015) 7:314ra186. doi:10.1126/scitranslmed. aac7433

24. Saunders LR, Bankovich AJ, Anderson WC, Aujay MA, Bheddah S, Black K, et al. A DLL3-targeted antibody-drug conjugate eradicates high-grade pulmonary neuroendocrine tumor-initiating cells in vivo. Sci Transl Med (2015) 7:302ra136. doi:10.1126/scitranslmed.aac 9459

25. Smith L, Nesterova A, Ryan MC, Duniho S, Jonas M, Anderson M, et al. CD133/prominin-1 is a potential therapeutic target for antibody-drug conjugates in hepatocellular and gastric cancers. Br J Cancer (2008) 99(1):100-9. doi:10.1038/sj.bjc.6604437

26. Medema JP. Cancer stem cells: the challenges ahead. Nat Cell Biol (2013) 15:338-44. doi:10.1038/ncb2717

27. Beck A, Goetsch L, Dumontet C, Corvaïa N. Strategies and challenges for the next generation of antibody-drug conjugates. Nat Rev Drug Discov (2017) 16:315. doi:10.1038/nrd.2016.268

28. Arteaga MF, Mikesch JH, Fung TK, So CWE. Epigenetics in acute promyelocytic leukaemia pathogenesis and treatment response: a TRAnsition to targeted therapies. Br J Cancer (2015) 112:413-8. doi:10.1038/bjc.2014.374

29. Witt AE, Lee CW, Lee TI, Azzam DJ, Wang B, Caslini C, et al. Identification of a cancer stem cell-specific function for the histone deacetylases, HDAC1 and HDAC7, in breast and ovarian cancer. Oncogene (2016) 36:1707. doi:10.1038/ onc. 2016.337

30. Oh SJ, Noh KH, Lee YH, Hong SO, Song KH, Lee HJ, et al. Targeting stemness is an effective strategy to control EML4-ALK+ non-small cell lung cancer cells. Oncotarget (2015) 6:40255-67. doi:10.18632/oncotarget.5434

31. Takahashi K, Yamanaka S. Induction of pluripotent stem cells from mouse embryonic and adult fibroblast cultures by defined factors. Cell (2006) 126:663-76. doi:10.1016/j.cell.2006.07.024

32. Song WS, Yang YP, Huang CS, Lu KH, Liu WH, Wu WW, et al. Sox2, a stemness gene, regulates tumor-initiating and drug-resistant properties in CD133-positive glioblastoma stem cells. J Chin Med Assoc (2016) 79:538-45. doi:10.1016/j.jcma.2016.03.010

33. Villodre ES, Kipper FC, Pereira MB, Lenz G. Roles of OCT4 in tumorigenesis, cancer therapy resistance and prognosis. Cancer Treat Rev (2016) 51:1-9. doi:10.1016/j.ctrv.2016.10.003

34. Guo Y, Liu S, Wang P, Zhao S, Wang F, Bing L, et al. Expression profile of embryonic stem cell-associated genes Oct4, Sox2 and Nanog in human gliomas. Histopathology (2011) 59:763-75. doi:10.1111/j.1365-2559.2011.03993.x

35. van Schaijik B, Davis PF, Wickremesekera AC, Tan ST, Itinteang T. Subcellular localisation of the stem cell markers OCT4, SOX2, NANOG, KLF4 and c-MYC in cancer: a review. JClin Pathol (2018) 71:88-91. doi:10.1136/ jclinpath-2017-204815

36. Di J, Duiveman-de Boer T, Zusterzeel PL, Figdor CG, Massuger LF, Torensma R. The stem cell markers Oct4A, Nanog and C-Myc are expressed in rare ascites cells and tumor tissue of ovarian cancer patients. Cell Oncol (2013) 36:363-74. doi:10.1007/s13402-013-0142-8

37. Zhao S, Yuan Q, Hao H, Guo Y, Liu S, Zhang Y, et al. Expression of OCT4 pseudogenes in human tumours: lessons from glioma and breast carcinoma. J Pathol (2011) 223:672-82. doi:10.1002/path.2827

38. Bora-Singhal N, Nguyen J, Schaal C, Perumal D, Singh S, Coppola D, et al. YAP1 regulates OCT4 activity and SOX2 expression to facilitate self-renewal and vascular mimicry of stem-like cells. Stem Cells (2015) 33:1705-18. doi:10.1002/stem.1993

39. Wang M-L, Chiou S-H, Wu C-W. Targeting cancer stem cells: emerging role of Nanog transcription factor. Onco Targets Ther (2013) 6:1207-20. doi:10.2147/OTT.S38114

40. Mitsui K, Tokuzawa Y, Itoh H, Segawa K, Murakami M, Takahashi K, et al. The homeoprotein Nanog is required for maintenance of pluripotency in mouse epiblast and ES cells. Cell (2003) 113:631-42. doi:10.1016/S00928674(03)00393-3

41. Wen Y, Hou Y, Huang Z, Cai J, Wang Z. SOX2 is required to maintain cancer stem cells in ovarian cancer. Cancer Sci (2017) 108:719-31. doi:10.1111/ cas. 13186

42. Kenda Suster N, Frkovic Grazio S, Virant-Klun I, Verdenik I, Smrkolj S. Cancer stem cell-related marker NANOG expression in ovarian serous tumors: a clinicopathological study of 159 cases. Int J Gynecol Cancer (2017) 27(9):2006-13. doi:10.1097/IGC.0000000000001105

43. Wuebben EL, Rizzino A. The dark side of SOX2: cancer - a comprehensive overview. Oncotarget (2017) 8:44917-43. doi:10.18632/oncotarget.16570

44. Almozyan S, Colak D, Mansour F, Alaiya A, Al-Harazi O, Qattan A, et al. PD-L1 promotes OCT4 and Nanog expression in breast cancer stem cells by sustaining PI3K/AKT pathway activation. Int J Cancer (2017) 141:1402-12. doi:10.1002/ijc.30834

45. Siu MK, Wong ES, Kong DS, Chan HY, Jiang L, Wong OG, et al. Stem cell transcription factor NANOG controls cell migration and invasion via dysregulation of E-cadherin and FoxJ1 and contributes to adverse clinical outcome in ovarian cancers. Oncogene (2012) 32:3500. doi:10.1038/onc.2012.363 
46. Han J, Zhang F, Yu M, Zhao P, Ji W, Zhang H, et al. RNA interference-mediated silencing of NANOG reduces cell proliferation and induces G0/G1 cell cycle arrest in breast cancer cells. Cancer Lett (2012) 321:80-8. doi:10.1016/j. canlet.2012.02.021

47. Gawlik-Rzemieniewska N, Bednarek I. The role of NANOG transcriptional factor in the development of malignant phenotype of cancer cells. Cancer Biol Ther (2016) 17:1-10. doi:10.1080/15384047.2015.1121348

48. Chang DF, Tsai SC, Wang XC, Xia P, Senadheera D, Lutzko C. Molecular characterization of the human NANOG protein. Stem Cells (2009) 27: 812-21. doi:10.1634/stemcells.2008-0657

49. Fairbanks DJ, Maughan PJ. Evolution of the NANOG pseudogene family in the human and chimpanzee genomes. BMC Evol Biol (2006) 6:12. doi:10.1186/1471-2148-6-12

50. Booth HA, Holland PW. Eleven daughters of NANOG. Genomics (2004) 84:229-38. doi:10.1016/j.ygeno.2004.02.014

51. Gawlik-Rzemieniewska N, Galilejczyk A, Krawczyk M, Bednarek I. Silencing expression of the NANOG gene and changes in migration and metastasis of urinary bladder cancer cells. Arch Med Sci (2016) 12:889-97. doi:10.5114/ aoms.2015.55368

52. Ezeh UI, Turek PJ, Reijo RA, Clark AT. Human embryonic stem cell genes OCT4, NANOG, STELLAR, and GDF3 are expressed in both seminoma and breast carcinoma. Cancer (2005) 104:2255-65. doi:10.1002/ cncr. 21432

53. Zhang S, Balch C, Chan MW, Lai HC, Matei D, Schilder JM, et al. Identification and characterization of ovarian cancer-initiating cells from primary human tumors. Cancer Res (2008) 68:4311-20. doi:10.1158/00085472.CAN-08-0364

54. Chiou SH, Wang ML, Chou YT, Chen CJ, Hong CF, Hsieh WJ, et al. Coexpression of Oct4 and Nanog enhances malignancy in lung adenocarcinoma by inducing cancer stem cell-like properties and epithelial-mesenchymal transdifferentiation. Cancer Res (2010) 70:10433-44. doi:10.1158/0008-5472. CAN-10-2638

55. Wong OG, Cheung AN. Stem cell transcription factor NANOG in cancers is eternal youth a curse? Expert Opin Ther Targets (2016) 20:407-17. doi:10.1517/14728222.2016.1112791

56. Noh KH, Lee YH, Jeon JH, Kang TH, Mao CP, Wu TC, et al. Cancer vaccination drives Nanog-dependent evolution of tumor cells toward an immune-resistant and stem-like phenotype. Cancer Res (2012) 72:1717-27. doi:10.1158/0008-5472.CAN-11-3758

57. Lee HJ, Noh KH, Lee YH, Song KH, Oh SJ, Kim SY, et al. NANOG signaling promotes metastatic capability of immunoedited tumor cells. Clin Exp Metastasis (2015) 32:429-39. doi:10.1007/s10585-015-9717-2

58. Gong S, Li Q, Jeter CR, Fan Q, Tang DG, Liu B. Regulation of NANOG in cancer cells. Mol Carcinog (2015) 54:679-87. doi:10.1002/mc.22340

59. Noh KH, Kim BW, Song KH, Cho H, Lee YH, Kim JH, et al. Nanog signaling in cancer promotes stem-like phenotype and immune evasion. J Clin Invest (2012) 122:4077-93. doi:10.1172/JCI64057

60. Tsai L-L, Yu C-C, Chang Y-C, Yu C-H, Chou M-Y. Markedly increased Oct4 and Nanog expression correlates with cisplatin resistance in oral squamous cell carcinoma. J Oral Pathol Med (2011) 40:621-8. doi:10.1111/j. 1600-0714.2011.01015.x

61. Wang H, Liu B, Wang J, Li J, Gong Y, Li S, et al. Reduction of NANOG mediates the inhibitory effect of aspirin on tumor growth and stemness in colorectal cancer. Cell Physiol Biochem (2017) 44:1051-63. doi:10.1159/000485405

62. Ji W, Jiang Z. Effect of shRNA-mediated inhibition of Nanog gene expression on the behavior of human gastric cancer cells. Oncol Lett (2013) 6:367-74. doi:10.3892/ol.2013.1394

63. Eldeeb MA, Hasani IW. Cancer vaccination and targeting Nanog for enhanced CTL-mediated immune response. J Cancer Prev Curr Res (2015) 3:78-9. doi:10.15406/jcpcr.2015.03.00078

64. Ding Y, Yu AQ, Li CL, Fang J, Zeng Y, Li DS. TALEN-mediated Nanog disruption results in less invasiveness, more chemosensitivity and reversal of EMT in Hela cells. Oncotarget (2014) 5:8393-401. doi:10.18632/oncotarget.2298

65. Kawamura N, Nimura K, Nagano H, Yamaguchi S, Nonomura N, Kaneda Y. CRISPR/Cas9-mediated gene knockout of NANOG and NANOGP8 decreases the malignant potential of prostate cancer cells. Oncotarget (2015) 6:22361-74. doi:10.18632/oncotarget.4293

66. Rad SM, Bamdad T, Sadeghizadeh M, Arefian E, Lotfinia M, Ghanipour M. Transcription factor decoy against stem cells master regulators, Nanog and
Oct-4: a possible approach for differentiation therapy. Tumour Biol (2015) 36:2621-9. doi:10.1007/s13277-014-2884-y

67. Zapperi S, La Porta CA. Do cancer cells undergo phenotypic switching? The case for imperfect cancer stem cell markers. Sci Rep (2012) 2:441. doi:10.1038/srep00441

68. Campos-Sanchez E, Cobaleda C. Tumoral reprogramming: plasticity takes a walk on the wild side. Biochim Biophys Acta (2015) 1849:436-47. doi:10.1016/j.bbagrm.2014.07.003

69. Di J, Duiveman-de Boer T, Figdor CG, Torensma R. Eradicating cancer cells: struggle with a chameleon. Oncotarget (2011) 2:99-101. doi:10.18632/ oncotarget. 222

70. Garcia-Mazas C, Csaba N, Garcia-Fuentes M. Biomaterials to suppress cancer stem cells and disrupt their tumoral niche. Int J Pharm (2017) 523:490-505. doi:10.1016/j.ijpharm.2016.12.013

71. Auffinger B, Tobias AL, Han Y, Lee G, Guo D, Dey M, et al. Conversion of differentiated cancer cells into cancer stem-like cells in a glioblastoma model after primary chemotherapy. Cell Death Differ (2014) 21:1119-31. doi:10.1038/cdd.2014.31

72. Brawley C, Matunis E. Regeneration of male germline stem cells by spermatogonial dedifferentiation in vivo. Science (2004) 304:1331-4. doi:10.1126/ science. 1097676

73. Webb JR, Milne K, Nelson BH. Location, location, location: CD103 demarcates intraepithelial, prognostically favorable CD8 tumor-infiltrating lymphocytes in ovarian cancer. Oncoimmunology (2014) 3:e27668. doi:10.4161/ onci. 27668

74. Galon J, Costes A, Sanchez-Cabo F, Kirilovsky A, Mlecnik B, LagorcePagès C, et al. Type, density, and location of immune cells within human colorectal tumors predict clinical outcome. Science (2006) 313:1960-4. doi:10.1126/science.1129139

75. Finocchiaro G, Pellegatta S. Immunotherapy with dendritic cells loaded with glioblastoma stem cells: from preclinical to clinical studies. Cancer Immunol Immunother (2015) 65(1):101-9. doi:10.1007/s00262-015-1754-9

76. Dhodapkar KM, Feldman D, Matthews P, Radfar S, Pickering R, Turkula S, et al. Natural immunity to pluripotency antigen OCT4 in humans. Proc Natl Acad Sci U S A (2010) 107:8718-23. doi:10.1073/pnas.0915086107

77. Di J, Massuger LF, Duiveman-de Boer T, Zusterzeel PL, Figdor CG, Torensma R. Functional OCT4-specific CD4 and CD8 T cells in healthy controls and ovarian cancer patients. Oncoimmunology (2013) 2:e24271. doi:10.4161/onci.24271

78. Bryant CE, Sutherland S, Kong B, Papadimitrious MS, Fromm PD, Hart DNJ. Dendritic cells as cancer therapeutics. Semin Cell Dev Biol (2018). doi:10.1016/j.semcdb.2018.02.015

79. Eleftheriadis T, Yiannaki E, Antoniadi G, Liakopoulos V, Pissas G, Galaktidou G, et al. Plasma indoleamine 2,3-dioxygenase and arginase type I may contribute to decreased blood T-cell count in hemodialysis patients. Ren Fail (2012) 34:1118-22. doi:10.3109/0886022X.2012.713297

80. Munn DH, Bronte V. Immune suppressive mechanisms in the tumor microenvironment. Curr Opin Immunol (2016) 39:1-6. doi:10.1016/j.coi. 2015.10.009

81. Yigit R, Massuger LF, Figdor CG, Torensma R. Ovarian cancer creates a suppressive microenvironment to escape immune elimination. Gynecol Oncol (2010) 117:366-72. doi:10.1016/j.ygyno.2010.01.019

82. Sun Z, Han Q, Zhu Y, Li Z, Chen B, Liao L, et al. NANOG has a role in mesenchymal stem cells' immunomodulatory effect. Stem Cells Dev (2011) 20:1521-8. doi:10.1089/scd.2010.0366

83. Wefers C, Duiveman-de Boer T, Zusterzeel PLM, Massuger LFAG, Fuchs $\mathrm{D}$, Torensma $\mathrm{R}$, et al. Different lipid regulation in ovarian cancer: inhibition of the immune system. Int J Mol Sci (2018) 19:273. doi:10.3390/ ijms19010273

84. Pardoll DM. The blockade of immune checkpoints in cancer immunotherapy. Nat Rev Cancer (2012) 12:252-64. doi:10.1038/nrc3239

85. Hirohashi Y, Torigoe T, Tsukahara T, Kanaseki T, Kochin V, Sato N. Immune responses to human cancer stem-like cells/cancer-initiating cells. Cancer Sci (2016) 107:12-7. doi:10.1111/cas.12830

86. Hoogstad-van Evert JS, Cany J, van den Brand D, Oudenampsen M, Brock R, Torensma R, et al. Umbilical cord blood CD34+ progenitor-derived NK cells efficiently kill ovarian cancer spheroids and intraperitoneal tumors in NOD/ SCID/IL2Rgnull mice. Oncoimmunology (2017) 6:e1320630. doi:10.1080/ 2162402X.2017.1320630 
87. Tirosh I, Venteicher AS, Hebert C, Escalante LE, Patel AP, Yizhak $\mathrm{K}$, et al. Single-cell RNA-seq supports a developmental hierarchy in human oligodendroglioma. Nature (2016) 539:309-13. doi:10.1038/ nature20123

88. Garrido F, Ruiz-Cabello F, Aptsiauri N. Rejection versus escape: the tumor MHC dilemma. Cancer Immunol Immunother (2017) 66:259-71. doi:10.1007/ s00262-016-1947-x

89. Garrido F, Aptsiauri N, Doorduijn EM, Garcia Lora AM, van Hall T. The urgent need to recover MHC class I in cancers for effective immunotherapy. Curr Opin Immunol (2016) 39:44-51. doi:10.1016/j.coi.2015.12.007

90. Lampen MH, van Hall T. Strategies to counteract MHC-I defects in tumors. Curr Opin Immunol (2011) 23:293-8. doi:10.1016/j.coi.2010.12.005

91. Ott PA, Hu Z, Keskin DB, Shukla SA, Sun J, Bozym DJ, et al. An immunogenic personal neoantigen vaccine for patients with melanoma. Nature (2017) 547:217-21. doi:10.1038/nature22991

92. Zamora AE, Crawford JC, Thomas PG. Hitting the target: how T cells detect and eliminate tumors. J Immunol (2018) 200:392-9. doi:10.4049/ jimmunol.1701413

93. Codd AS, Kanaseki T, Torigo T, Tabi Z. Cancer stem cells as targets for immunotherapy. Immunology (2018) 153:304-14. doi:10.1111/imm.12866

94. Pellegatta S, Poliani PL, Corno D, Menghi F, Ghielmetti F, Suarez-Merino B, et al. Neurospheres enriched in cancer stem-like cells are highly effective in eliciting a dendritic cell-mediated immune response against malignant gliomas. Cancer Res (2006) 66:10247-52. doi:10.1158/0008-5472.CAN06-2048

95. Vogelstein B, Papadopoulos N, Velculescu VE, Zhou S, Diaz LA Jr, Kinzler KW. Cancer genome landscapes. Science (2013) 339:1546-58. doi:10.1126/science.1235122

96. Corse E, Gottschalk RA, Allison JP. Strength of TCR-peptide/MHC interactions and in vivo T cell responses. J Immunol (2011) 186:5039-45. doi:10.4049/jimmunol.1003650

97. Hoof I, Peters B, Sidney J, Pedersen LE, Sette A, Lund O, et al. NetMHCpan, a method for MHC class I binding prediction beyond humans. Immunogenetics (2009) 61:1-13. doi:10.1007/s00251-008-0341-Z

98. Bakker AB, Schreurs MW, de Boer AJ, Kawakami Y, Rosenberg SA, Adema GJ, et al. Melanocyte lineage-specific antigen gp100 is recognized by melanoma-derived tumor-infiltrating lymphocytes. J Exp Med (1994) 179:1005-9. doi:10.1084/jem.179.3.1005

99. Kawakami Y, Eliyahu S, Jennings C, Sakaguchi K, Kang X, Southwood S, et al. Recognition of multiple epitopes in the human melanoma antigen gp100 by tumor-infiltrating $\mathrm{T}$ lymphocytes associated with in vivo tumor regression. J Immunol (1995) 154:3961-8.

100. Friedrich J, Seidel C, Ebner R, Kunz-Schughart LA. Spheroid-based drug screen: considerations and practical approach. Nat Protoc (2009) 4:309-24. doi:10.1038/nprot.2008.226

101. Sato F, Kubota Y, Natsuizaka M, Maehara O, Hatanaka Y, Marukawa K, et al. EGFR inhibitors prevent induction of cancer stem-like cells in esophageal squamous cell carcinoma by suppressing epithelial-mesenchymal transition. Cancer Biol Ther (2015) 16(6):933-40. doi:10.1080/15384047.2015. 1040959

102. Chen J, Wang J, Zhang Y, Chen D, Yang C, Kai C, et al. Observation of ovarian cancer stem cell behavior and investigation of potential mechanisms of drug resistance in three-dimensional cell culture. J Biosci Bioeng (2014) 118:214-22. doi:10.1016/j.jbiosc.2014.01.008
103. Feder-Mengus C, Ghosh S, Reschner A, Martin I, Spagnoli GC. New dimensions in tumor immunology: what does 3D culture reveal? Trends $\mathrm{Mol} \mathrm{Med}$ (2008) 14:333-40. doi:10.1016/j.molmed.2008.06.001

104. Qureshi-Baig K, Ullmann P, Rodriguez F, Frasquilho S, Nazarov PV, Haan S, et al. What do we learn from spheroid culture systems? Insights from tumorspheres derived from primary colon cancer tissue. PLoS One (2016) 11:e0146052. doi:10.1371/journal.pone.0146052

105. Ravi M, Ramesh A, Pattabhi A. Contributions of 3D cell cultures for cancer research. J Cell Physiol (2016) 232(10):2679-97. doi:10.1002/jcp. 25664

106. Sato T, Stange DE, Ferrante M, Vries RG, Van Es JH, Van den Brink S, et al. Long-term expansion of epithelial organoids from human colon, adenoma, adenocarcinoma, and Barrett's epithelium. Gastroenterology (2011) 141:1762-72. doi:10.1053/j.gastro.2011.07.050

107. Bredenoord AL, Clevers H, Knoblich JA. Human tissues in a dish: the research and ethical implications of organoid technology. Science (2017) 355:eaaf9414. doi:10.1126/science.aaf9414

108. Vlachogiannis G, Hedayat S, Vatsiou A, Jamin Y, Fernández-Mateos J, Khan K, et al. Patient-derived organoids model treatment response of metastatic gastrointestinal cancers. Science (2018) 359:920-6. doi:10.1126/ science.aao 2774

109. Lancaster MA, Knoblich JA. Organogenesis in a dish: modeling development and disease using organoid technologies. Science (2014) 345:1247125. doi:10.1126/science.1247125

110. Clevers H. Modeling development and disease with organoids. Cell (2016) 165:1586-97. doi:10.1016/j.cell.2016.05.082

111. Praharaj PP, Bhutia SK, Nagrath S, Bitting RL, Deep G. Circulating tumor cell-derived organoids: current challenges and promises in medical research and precision medicine. Biochim Biophys Acta (2018) 1869:117-27. doi:10.1016/j.bbcan.2017.12.005

112. Halo TL, McMahon KM, Angeloni NL, Xu Y, Wang W, Chinen AB, et al. NanoFlares for the detection, isolation, and culture of live tumor cells from human blood. Proc Natl Acad Sci U S A (2014) 111:17104-9. doi:10.1073/ pnas. 1418637111

113. McClellan S, Slamecka J, Howze P, Thompson L, Finan M, Rocconi R, et al. mRNA detection in living cells: a next generation cancer stem cell identification technique. Methods (2015) 82:47-54. doi:10.1016/j.ymeth. 2015.04.022

114. Wefers C, Bakdash G, Moreno Martin M, Duiveman-de Boer T, Torensma $\mathrm{R}$, Massuger LF, et al. Isolation of Mononuclear Cell Populations from Ovarian Carcinoma Ascites. Bio-protocol (2017) 7(7):e2219. doi:10.21769/ BioProtoc. 2219

Conflict of Interest Statement: The authors declare that the research was conducted in the absence of any commercial or financial relationships that could be construed as a potential conflict of interest.

Copyright (c) 2018 Wefers, Schreibelt, Massuger, de Vries and Torensma. This is an open-access article distributed under the terms of the Creative Commons Attribution License (CC BY). The use, distribution or reproduction in other forums is permitted, provided the original author(s) and the copyright owner are credited and that the original publication in this journal is cited, in accordance with accepted academic practice. No use, distribution or reproduction is permitted which does not comply with these terms. 